\title{
Direct Problem-Based Learning (DPBL): A Framework for Integrating Direct Instruction and Problem-Based Learning Approach
}

\author{
Sri Winarno ${ }^{1}$, Kalaiarasi Sonai Muthu ${ }^{2} \&$ Lew Sook Ling ${ }^{2}$ \\ ${ }^{1}$ Faculty of Computer Science, Dian Nuswantoro University, Semarang, Indonesia \\ ${ }^{2}$ Faculty of Information Science and Technology, Multimedia University, Melaka, Malaysia \\ Correspondence: Sri Winarno, Faculty of Computer Science, Dian Nuswantoro University, Semarang 50131, \\ Indonesia. E-mail: fattahmg@gmail.com
}

Received: August 29, 2017

doi:10.5539/ies.v11n1p119

\author{
Accepted: September 30, 2017 \\ Online Published: December 29, 2017 \\ URL: https://doi.org/10.5539/ies.v11n1p119
}

\begin{abstract}
.
Direct instruction approach has been widely used in higher education. Many studies revealed that direct instruction improved students' knowledge. The characteristics of direct instruction include the subject delivered through face-to-face interaction with the lecturers and materials that sequenced deliberately and taught explicitly. However, direct instruction resulted in low creative thinking and teamwork skills among students. Therefore, problem-based learning activities were adapted to reform and create an innovation of a direct instruction approach in developing the new situation.
\end{abstract}

Objective: This study aimed at exploring lecturers' and students' perspectives towards Direct Problem-Based Learning (DPBL) activities as a new approach for activities in the classroom.

Design: A quasi-experimental design was used.

Participants: Third-year students $(\mathrm{N}=276)$ who signed up for Computer Networks subject from Dian Nuswantoro University, Indonesia and five lecturers were involved.

Findings and Results: Learning outcomes were significantly positively (Sig. $\mathrm{p}=.00$ ). Creative thinking skills score increased $8.4 \%$, Teamwork skills score increased $11.5 \%$, and knowledge score increased $25.9 \%$ of DPBL approach. The majority of students have difficulties in the direct instruction approach $\bar{x}=4.71(.472)$. Whereas, $\overline{\boldsymbol{x}}=1.99(.655)$ students have low difficulty in DPBL approach. Expert participants agreed that DPBL approach can enhance creative thinking and teamwork skills $\bar{x}=4.70(.50)$.

Keywords: direct instruction, problem-based learning, direct problem-based learning, problem-solving skills, creative thinking skills, teamwork skills

\section{Introduction}

Direct instruction approach (DIA) has been widely used in higher education. The computer network subject (Vinay \& Rassak, 2015) is one of the courses that applied DIA. Many studies revealed that DIA is the best teaching strategies to improve students' knowledge (Hattie, 2009; Stockard, 2010; Flynn et al., 2012; Robert et al., 2014; Gurses et al., 2015). The characteristics of DIA include the delivery of subject through the face-to-face interaction with the lecturers, materials that are sequenced deliberately and taught explicitly, and division of the students into small groups (Carnine, 2000, pp. 5-6). However, there are many disadvantages of DIA. One of them is that it decreases students' problem-solving skills (Choi et al., 2014).

Problem-solving skills refer to the students' ability to investigate the solution to a given problem or find a way to realise the given aim (Zhong et al., 2010). Many ways in order to solve a problem involve capability in creative thinking and group discussion or teamwork (Siswono, 2014; Sockalingam, 2010). Creative thinking is necessary for coming up with ideas for resolving the problem and finding a fresh approach. Meanwhile, team working is often a key component to solve a problem.

Problem-based learning is the instructional approach in which students learn about a subject through the experience of solving an open-ended problem. As an approach to improve problem-solving skills, problem-based learning is considered as the most appropriate teaching method. Problem-based learning is described as an inquiry-based approach that is student-centred and builds problem-solving skills (Becker \& Maunsaiyat, 2004; 
Blumberg, 2000; Chen et al., 2001). One of the characteristics of problem-based learning is the students work in small groups usually no larger than nine students. It helps the lecturers to easily monitor the learning environment and increase students' problem-solving skills (Yusof et al., 2012; Choi et al., 2014). Barrow (1996) and Savery (2006) showed more than ten characteristics of problem-based learning. However, this study only adopted four characteristics as follows (1) Learner-centred approach where students engage with the problems related to whatever current knowledge or experience they afford; (2) Ill-structured problems in the real world; (3) Lecturers take the role of a tutor or facilitator; and (4) Students work in small groups usually no larger than nine students.

Currently, teaching and learning processes in Computer Network subject in the Dian Nuswantoro University of Indonesia are using DIA, which is an approach to teaching; it is skill-oriented, and the teaching practices are teacher-directed (Carnine, 2000). However, this strategy has caused low creative thinking and teamwork skills among students. Therefore, the reformation and innovation of DIA of Computer Networks are imperative in the new development situation.

This study discusses impacts of the Direct Problem-Based Learning (DPBL) activities toward students' knowledge, creative thinking, and teamwork skills. The DPBL activities are a combination of direct instruction and problem-based learning activities. The current study aims to investigate to what extent are the impacts of DPBL teaching approach versus direct instruction education on creative thinking and teamwork skills of Computer Networks students in Dian Nuswantoro University, Indonesia.

Three phases of the UTM PBL model were developed. The first phase was the problem restatement and identification in which the students read the problem scenario, reflect, and articulate probable issues individually. The second phase was learning application and solution which deal with peer learning, synthesis, and application. The last phase was generalisation closure and internalisation which deal with the presentation, reflection, team rating, and feedback (Yusof et al., 2012).

\section{Purpose and Scope of the Study}

This study aimed at exploring lecturers' and students' perspectives toward DPBL activities as a new approach for activities in the classroom. DPBL activities are a combination of the Direct Instruction and Problem-Based Learning activities. This model was designed as an alternative teaching approach to improve students' knowledge, creative thinking, and teamwork skills. Meanwhile, the scope of this study was the third-year students $(\mathrm{N}=276)$ who took Computer Networks as a subject in Dian Nuswantoro University, Indonesia.

The DPBL conceptual framework (Figure 1) was developed from direct instruction (Carnine, 2000, pp. 5-6) and problem-based learning activities (Barrows, 1996; Savery, 2006) to enhance students' knowledge, creative thinking, and teamwork skills. The DPBL integrated model (Figure 2) was modified from the UTM PBL frameworks.

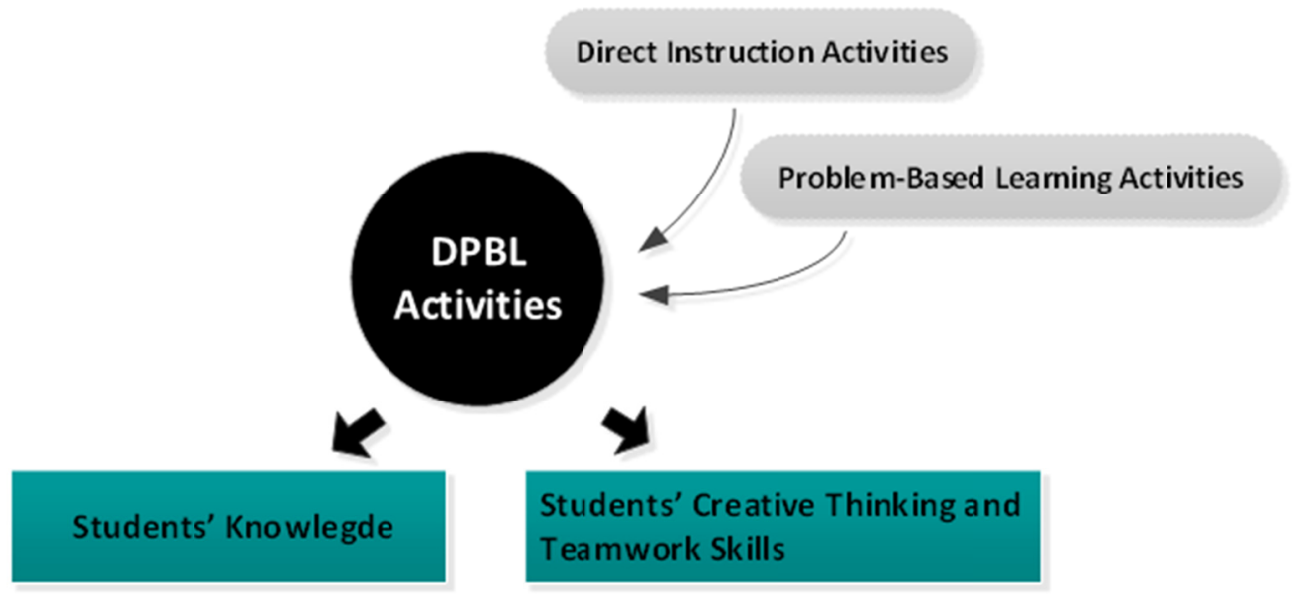

Figure 1. Conceptual approach 


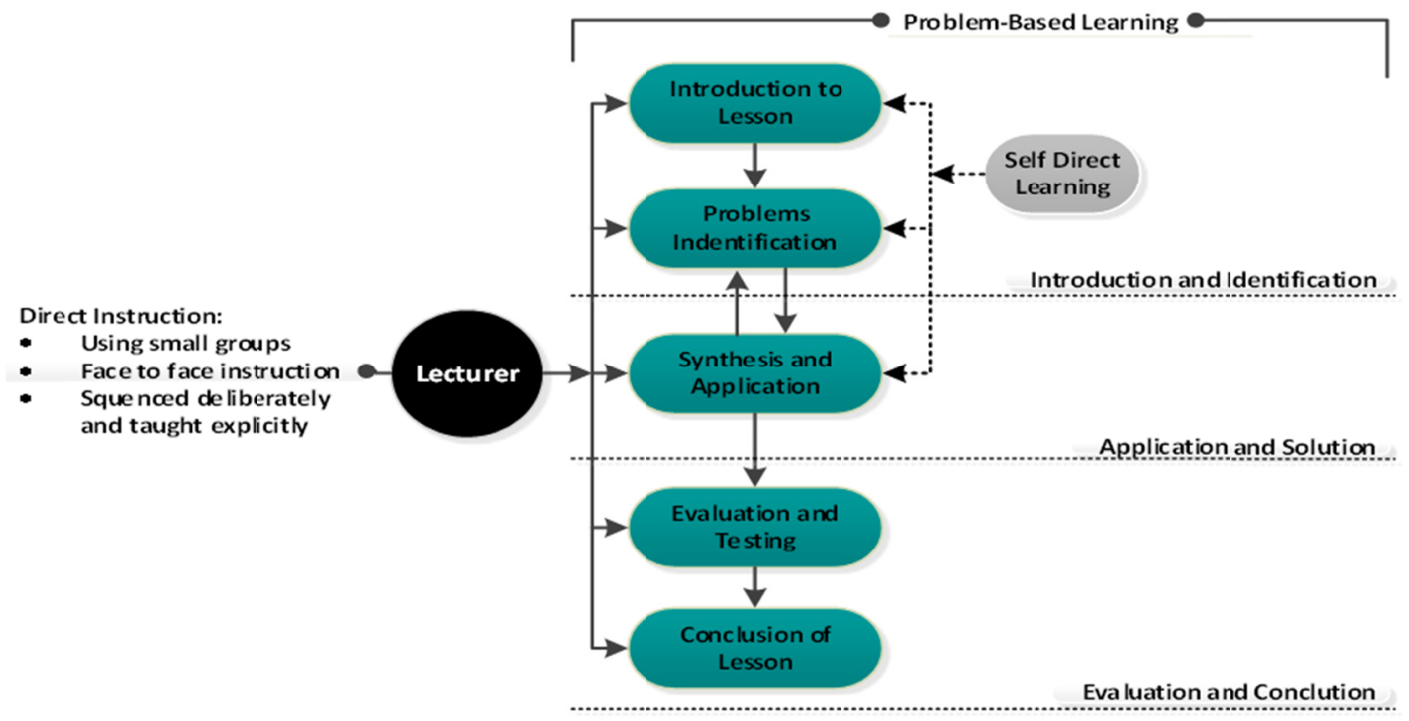

Figure 2. The DPBL integrated approach

The DPBL model consists of three main phases: The introduction and identification, application and solution, and evaluation and conclusion. The description of phases is as follows:

Phase 1: Instruction and Identification:

This phase consists of two steps, namely instruction to the lesson and problem identification. In this phase, the lecturer explains the purpose of the learning activity and objective and the theory of the subject as well as to help the students in searching, finding, and resolving the problem during the teaching and learning process.

Phase 2: Application and Solution:

The lecturer and students are engaged in synthesising the related data and final solution.

Phase 3: Evaluation and Conclusion:

The lecturer and students are engaged in presenting the final report, summarising the concepts description, and closing the lesson.

\section{Method}

The research was performed in Dian Nuswantoro University, Indonesia. Two departments (i.e. Informatics Engineering and Information System Department) were involved.

\subsection{Design and Sample}

The quasi-experimental group pre-test and post-test designs were used. The third-year students $(\mathrm{N}=276)$ who took Computer Networks from two departments in Dian Nuswantoro University, Indonesia were involved. In two selected educational programs, one used DIA that consists of 140 students, while the other used DPBL approach that consists of 136 students. Five lecturers teaching Computer Networks in the sample class also participated in this study.

\subsection{Instrument and Procedure}

The protocol was reviewed and ethical permission for the study was received from the university through each department. The DPBL and direct instruction program approaches were conducted over one semester comprising 14 weeks. Students in both groups completed the demographic form and creative thinking, teamwork, and knowledge questionnaires at the same time, prior to direct instruction and DPBL lecture instruction. For the DPBL group, there were 136 students assigned to 25 DPBL groups, where each DPBL group consisted of five to six students. The DPBL group session was 2 hour per week for 3 weeks.

\subsection{Pilot Study}

A pilot study was conducted on thirty undergraduate students and five lecturers to determine the reliability of the tools. The Cronbach's Alpha coefficient for the questionnaires in the pilot study was .797. In general, the 
respondents of the pilot study gave positive feedback toward the general structure and presentation of the questionnaire, the survey questionnaire was further refined to improve the face validity of the scales based on some comments collected from the participants. In order to assess the face and content validities, and to ensure its adaptability to the local cultural context, the instrument was reviewed and approved by the Faculty of Computer Sciences, Dian Nuswantoro University, Indonesia.

\subsection{Data Analysis}

Standardised questionnaires of creative thinking, teamwork, and knowledge abilities were administered before and at after 16 weeks (after instruction). IBM SPSS statistics 21 was used to analyse the data. The frequencies and descriptive analyses and t-test were employed to compare the baseline measurements of demographic and dependent variables between the two groups using five criteria for evaluation according to Likert scale.

\section{Results}

DPBL activities were set in the DPBL phases. The DPBL activities are shown as follows:

Phase 1: Introduction and Identification

Introduction to Lesson

1) The lecturer starts the lesson and explains the purpose of the learning activity.

2) The lecturer divides the students into small groups in a class which consist of five to six members.

3) The lecturer gives suggestions on how to work in groups and explains the role of group members and criteria of the works.

Problem Identification

1) The lecturer presents the theory and objectives of learning.

2) The lecturer presents step-by-step progress from one subtopic to other subtopics.

3) The lecturer presents the problem and final solution.

4) The lecturer asks the students to find, identify, and analyse the problem.

5) The lecturer monitors group activities in the class through discussion conducted by each group or group members.

Phase 2: Application and Solution

1) The groups define the real world problem and final solution.

2) The groups define the assumptions and learning objectives.

3) The groups search the data related, data synthesis, application, and final solution.

4) The lecturer monitors the groups' behaviour as well as provides advice and suggestions.

Phase 3: Evaluation and Conclusion

1) The groups present their work report.

2) The groups present the concepts and characteristics of problem-solving.

3) The lecturer and groups share their ideas to achieve the learning goals.

4) The lecturer explains and summarises the concepts and then closes the lesson.

Figure 3 depicts the teaching and learning situation using DPBL activities. The lecturer divides the students into small groups in a class which consist of five to six members. The lecturer gave suggestions on how to work in groups, explained the role of group members and criteria of the works. The lecturer presented step-by-step progress from one subtopic to other subtopics. The lecturer presented the problem and final solution. The groups defined the real world's problem and final solution. The lecturer explained and summarised the concepts and then stopped the lesson. 


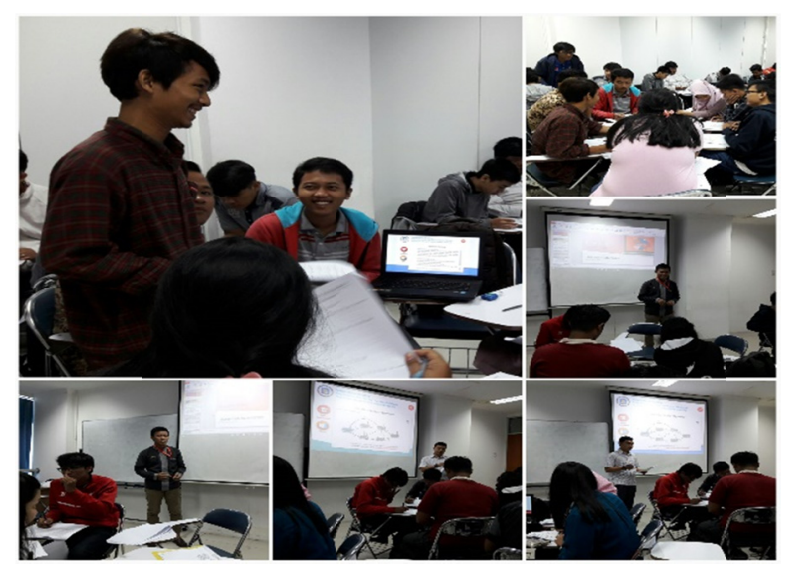

Figure 3. Teaching and learning situation using DPBL activities

Table 1 presents comparison demographic of the students in the direct instruction group versus DPBL group. The age was divided into two categories. Nearly all participants were under 20 years of age. Meanwhile, the gender of direct instruction group showed 101 males $(72.1 \%)$ and 39 females $(27.9 \%)$, while 92 males $(67.6 \%)$ and 44 females $(32.4 \%)$ of DPBL group. Nearly all participants were male.

Table 1. Demographic of students in the control $(\mathrm{N}=140)$ and DPBL $(\mathrm{N}=136)$ groups

\begin{tabular}{cccccc}
\hline \multirow{2}{*}{ Demographic } & \multicolumn{2}{c}{ Control Group } & \multicolumn{2}{c}{ DPBL Group } \\
& & \multicolumn{2}{c}{$\mathrm{N}(\%)$} & \multicolumn{2}{c}{$\mathrm{N}(\%)$} \\
\hline \multirow{2}{*}{ Gender } & Male & 101 & $(72.1)$ & 92 & $(67.6)$ \\
& Female & 39 & $(27.9)$ & 44 & $(32.4)$ \\
\multirow{2}{*}{ Age } & $18<$ Age $<20$ & 119 & $(85.0)$ & 210 & $(88.2)$ \\
& $21<$ Age $<26$ & 21 & $(15.0)$ & 67 & $(11.8)$ \\
\hline
\end{tabular}

Table 2 presents the comparison mean score of the students in the direct instruction group versus DPBL group. There is a mean score difference between the direct instruction and DPBL approaches (Figure 3). Mean score of direct instruction group showed $\overline{\boldsymbol{x}}=18.01$ of creative thinking skills, $\overline{\boldsymbol{x}}=21.61$ of teamwork skills, and $\overline{\boldsymbol{x}}=32.06$ of knowledge. Meanwhile, DPBL group showed $\overline{\boldsymbol{x}}=19.67$ of creative thinking skills, $\overline{\boldsymbol{x}}=24.42$ of teamwork skills, and $\bar{x}=43.28$ of knowledge.

Learning outcomes were significantly positive [Sig. (2-tailed) $p=.00]$. There is a mean score difference between direct instruction and DPBL approaches. Creative thinking skills score increased 1.66 points $(8.4 \%)$, teamwork skills score increased 2.81 points (11.5\%), and knowledge score increased 11.22 points $(25.9 \%)$.

Table 2. Descriptive test between groups based on abilities

\begin{tabular}{lcccccccc}
\hline \multirow{3}{*}{ Variables } & \multicolumn{3}{c}{ Frequencies } & \multicolumn{5}{c}{ t-test for Equality of Mean } \\
\cline { 2 - 8 } & $\begin{array}{c}\text { Control Group } \\
\overline{\boldsymbol{x}}(\mathbf{S D})\end{array}$ & $\begin{array}{c}\text { DPBL Group } \\
\overline{\boldsymbol{x}}(\mathbf{S D})\end{array}$ & $\mathrm{t}$ & $\mathrm{df}$ & $p$ & $\overline{\boldsymbol{x}}$ & Difference & Std. Error Difference \\
\hline Creative Thinking & $18.01(2.27)$ & $19.67(2.05)$ & -6.43 & 274 & $.000^{*}$ & -1.66 & .261 \\
Teamwork & $21.61(3.55)$ & $24.42(2.32)$ & -7.77 & 274 & $.000^{*}$ & -2.81 & .362 \\
Knowledge & $32.06(7.67)$ & $43.28(2.94)$ & -15.93 & 274 & $.000^{*}$ & -11.22 & .704 \\
\hline
\end{tabular}

* Significant at $\mathrm{p}<.05$. 


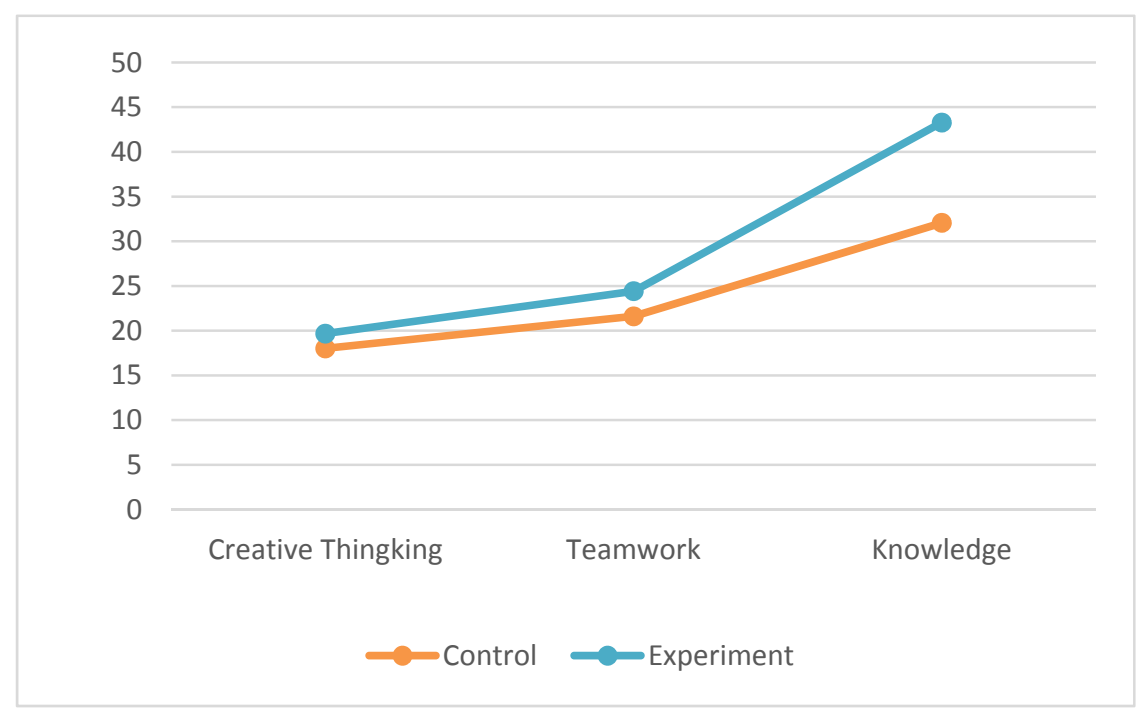

Figure 4. The mean score comparison of each group

Table 3 presents the comparison of students' difficulties and their perception scores toward direct instruction and DPBL approaches of each group. There are score differences between direct instruction and DPBL approach. The findings indicated that the majority of students had high difficulties in the direct instruction method $\overline{\boldsymbol{x}}=4.71(.47)$. Whereas, $\overline{\boldsymbol{x}}=1.99(.66)$ students had low difficulties in the DPBL teaching approach.

The majority of the students had a positive response toward DPBL teaching approach. $\bar{x}=4.80(.42)$ students had a positive response to DPBL teaching approach. Whereas, $\bar{x}=2.04(.72)$ students had low response toward direct instruction method.

Table 3. The evaluation student response of DPBL activities

\begin{tabular}{|c|c|c|c|c|c|c|c|}
\hline \multirow[b]{2}{*}{ Evaluation List } & \multicolumn{2}{|c|}{ Frequencies } & \multicolumn{5}{|c|}{ t-test for Equality of Mean } \\
\hline & $\begin{array}{c}\text { Control Group } \\
\bar{x}(\mathbf{S D})\end{array}$ & $\begin{array}{c}\text { DPBL Group } \\
\bar{x}(\mathbf{S D})\end{array}$ & $\mathrm{t}$ & df & $p$ & $\bar{x}$ Difference & Std. Error Difference \\
\hline Difficulties & $4.71(.47)$ & $1.99(.66)$ & 39.211 & 271 & $.000^{*}$ & 2.715 & .069 \\
\hline Effective approach & $2.04(.72)$ & $4.80(.42)$ & -38.402 & 271 & $.000 *$ & -2.758 & .072 \\
\hline
\end{tabular}

* Significant at $\mathrm{p}<.05$.

Table 4 shows the lecturers agree that DPBL activities were appropriate, which showed highest level $\overline{\boldsymbol{x}}=4.70$, S.D =.50). The mean scores of the possibility in using DPBL were $\overline{\boldsymbol{x}}=4.80(.45)$ and $\overline{\boldsymbol{x}}=4.60(.55)$ showing that DPBL is an effective approach.

Table 4. The evaluation of lecturers' responses of DPBL activities

\begin{tabular}{lrcc}
\hline \multirow{2}{*}{ Evaluation List } & \multicolumn{2}{c}{ Results } & Level of appropriateness \\
\cline { 2 - 4 } & $\overline{\boldsymbol{x}}$ & Std. Deviation & \\
\hline DPBL is possible to be used & 4.80 & .45 & Highest \\
DPBL is effective to improve creative thinking and teamwork skills & 4.60 & .55 & Highest \\
Summary & 4.70 & .50 & Highest \\
\hline
\end{tabular}

\section{Discussion}

DPBL is an alternative approach for teaching and learning process, especially to enhance students' knowledge, creative thinking, and teamwork skills. According to the assessment by participants, it was found that students felt low difficulties towards DPBL approach. In addition, it was found that DBPL is an effective approach to improve students' creative thinking and teamwork skills. This is a sample case study for supporting students to develop knowledge, creative thinking, and teamwork skills as the outcome of positive development and 
experiences while undergoing DPBL approach.

\section{Limitations}

This study has limitations. Results cannot be generalised to other settings because the study was employed with large samples of third-year Computer Networks students from two departments in Dian Nuswantoro University, Indonesia. Further research will be needed to further examine DPBL as an alternative approach to all levels of education, which require other representative samples. Quasi-experimental group pre-test and post-test designs were used. Participants came from only two departments to prevent the flaw between the experimental and control groups. However, there were differences between groups in baseline variables, and thus frequencies, descriptive, and t-test analysis were used.

\section{Conclusion}

Direct Problem-Based Learning (DPBL) was designed to improve students' knowledge, creative thinking, and teamwork skills in the teaching and learning process. From the model illustration, this model was simple and easy to be implemented in the classroom.

Learning outcomes were significantly positive. There were scores of differences between direct instruction and DPBL approach. The students' knowledge, creative thinking, and teamwork skills were increased. The findings indicated that the majority of students have difficulties in the direct instruction approach. Whereas, students had low difficulties in the DPBL teaching approach. The majority of the students showed a positive response towards DPBL teaching approach, whereas, students had low response toward the direct instruction method.

Nearly all lecturers agreed that DPBL approach can enhance students' creative thinking and teamwork skills. DPBL approach is considered appropriate for the high levels of education. Therefore, DPBL approach was suggested as an alternative approach for teaching process.

\section{Acknowledgements}

This research was supported by the Dian Nuswantoro University. The authors gratefully acknowledge the research assistance provided by the Dian Nuswantoro University, Indonesia.

\section{References}

Barrows, H. S. (1996). Problem-Based Learning in Medicine and Beyond: A Brief Overview. New Direction for Teaching and Learning, 68, 3-12. https://doi.org/10.1002/t1.37219966804

Beker, K. H., \& Maunsaiyat, S. (2004). A comparison of students; achievement and attitudes between constructivist and traditional classroom environment in Thailand vocational electronics programs. Journal of Vocational Education Research, 29(2), 133-153. https://doi.org/10.5328/JVER29.2.133

Blumberg, P. (2000). Evaluating the evidence that Problem-Based learners are self-directed learners: A review of the literature. In D. H. Evensen, \& E. E. Hmelo (Eds.), Problem-Based Learning: A research perspective on learning interactions (pp. 199-226). Mahwah, NJ: Erlbaum.

Carnine, D. W., Silbert, J., Kame'enui, E. J. \& Tarve, S. G. (2000). Direct Instruction Reading (pp. 5-6; Traub, 1999). Prentice Hall.

Chen, S. K., Chang, H. F., \& Chiang, C. P. (2001). Group learning factors in a Problem-Based course in oral radiology. Dento Maxillo Facial Radiology, 30(2), 84-87. doi:10.1038/sj/dmfr/4600577.

Choi, E., Lindquist, R., \& Song Y. (2014). Effect of Problem-Based Learning vs. Traditional lecture on Korean nursing students' critical thinking, problem-solving, and self-directed learning. Nurse Education Today, 34, 52-56. https://doi.org/10.1016/j.nedt.2013.02.012

Flynn, R. J., Marquis, R. A., Paquet, M. P., Peeke, L. M., \& Daubry, T. D. (2012). Effects of individual direct-instruction tutoring on foster children's academic skills: A randomized trial. Children and Youth Services Review, 34, 1183-1189. https://doi.org/10.1016/j.childyouth.2012.01.036

Guses, A., Dogar, C., \& Gunesm K. (2015). A New Approach for Learning: Interactive Direct Teaching Based Constructivist Learning (IDTBCCL). Procedia-Social and Behavioral Sciences, 197, 2384-2389. https://doi.org/10.1016/j.sbspro.2015.07.296

Hattie, J. (2009). Visible learning: A synthesis of over 800 meta-analyses relating to achievement. London and New York: Routledge.

Leary, H. M. (2012). Self-Direct Learning in Problem-Based Learning Versus Traditional Lecture-Based 
Learning: A Meta-Analysis. All Graduate Theses and Dissertation. Paper 1173.

Mattews, B. (2004). The effects of direct and Problem-Based Learning instruction in an undergraduate introductory engineering graphics course (Unpublished doctoral dissertation). North California State University.

Savery, J. R. (2006). Overview of Problem-Based Learning: Definition and Distinctions. The Interdisciplinary Journal of Problem-Based Learning, 1(1), 9-20. https://doi.org/10.7771/1541-5015.1002

Siswono, T. Y. E. (2014). Developing Teacher Performances to Improving Students Creative Thinking Capabilities in Mathematics. Proceeding of International Conference on Research, Implementation and Education of Mathematics and Sciences.

Sockalingam, N. (2010). Characteristics of Problems in Problem-Based Learning. Dissertation, Erasmus University, Rotterdam.

Stockard, J. (2010). Improving elementary level mathematics achievement in a large urban district: The effects of Direct Instruction in the Baltimore City Public School System. Journal of Direct Instruction, 10, 1-16.

Tan, O. S. (2003). Problem-Based Learning Innovation: Using Problems to Power Learning in the 21st Century (p. 35). Thomson, Singapore.

Vinay, M., \& Rassak, S. (2015). A technological Framework for Teaching-Learning Process of Computer Networks to Increase the Learning Habit. International Journal of Computer Applications, 117(4). https://doi.org/10.5120/20539-2904

Yusof, K. M., Hasan, S. A. H. S., Jamaludin, M. Z., \& Harun, N. F. (2012). Cooperative Problem-Based Learning (CPBL): Framework for Integrating Cooperative Learning and Problem-Based Learning. Procedia-Social and Behavioral Sciences, 56, 223-232. https://doi.org/10.1016/j.sbspro.2012.09.649

Zhengmeng, C., \& Yanru, X. (2012). On the constructivist's teaching methods and class architects of securities investment. International symposium on information technology in medicine and education.

Zhong, N., Yingxu Wang, Y., \& Chiew, V. (2010). On the cognitive process of human problem-solving. Cognitive Systems Research, 11, 81-92. https://doi.org/10.1016/j.cogsys.2008.08.003

\section{Copyrights}

Copyright for this article is retained by the author(s), with first publication rights granted to the journal.

This is an open-access article distributed under the terms and conditions of the Creative Commons Attribution license (http://creativecommons.org/licenses/by/4.0/). 